\title{
STRATEGIC PARTNERSHIP FOR THE FUTURE OF COMMUNICATION STUDIES IN RUSSIA: SIBERIAN FEDERAL UNIVERSITY (SIBFU)
}

The Russian Journal of Communication (RJC) is pleased to announce its strategic, international academic partnership with Siberian Federal University (SibFU). The first of 10 federal universities in Russia, SibFU was established in November 2006 by merging four leading universities in Krasnoyarsk.

SibFU is well-positioned to support $R J C$. The university consists of 20 specialized schools and 3 affiliated institutions with more than 33000 students, 830 post-graduates, and 6600 employees. It offers 370 academic programmes, 20 of which are in English and provide the opportunity to get an international master's degree and Ph.D. There are 82 scientific laboratories in the university, one of which is headed by a Nobel Prize winner Osamu Shimomura. The eclectic offerings of SibFU makes it well-suited to support the broad scientific, artistic, and theoretical investigations that comprise communication study.

Another strength is SibFU's diversified student body. The university is proud to have a large number of students enrolled from different parts of Russia. In 2016, nearly 41000 admission applications were submitted from 67 regions. Sixty-five per cent of SibFU students are non-residents of Krasnoyarsk, coming mainly from the Siberian and Far Eastern federal districts. Eight hundred and thirty-one foreign students also call SibFU home.

Over the past 5 years, SibFU has been in the TOP-20 according to several Russian rating agencies. The university identified as the \#8 supplier of graduates meeting employers' demands for qualified workforce employees. In addition, SibFU was internationally recognized for its superior levels of excellence. In 2016, the university was honored by its rating by the international Times Higher Education. Also, SibFU is ranked in the TOP-200 in the universities of the BRICS countries rating, and the British rating agency $Q S$ awarded the university with 4 stars.

In 2015, SibFU joined Russian President Vladimir Putin's "5-100” project based on its renowned strength in the sciences and technology. SibFU's focus on integrating a scientific balance between nature and industrialization has forged the university's commitment toward enhancing Russia's international competitiveness while improving life quality and increasing life expectancy. The unique advantage of SibFU are its strategic partnerships with the largest Russian industrial companies to implement several investment projects in Krasnoyarsk Krai. Currently, several scientific and technological centres are being constructed around the university.

These scientific collaborations and centres complement SibFU's commitment towards the international scientific study of communication. The linguistic education provided by the university's School of Philology and Language Communication ranks $4^{\text {th }}$ in Russia. The School offers a wide range of academic programmes focused on European and Asian languages and cultures. SibFU offers an Intercultural Communication Master's programme of double diplomas conducted jointly with the Faculty of Philology of the University of Cadiz (Spain). Also, the university offers an annual course in Russian language acquisition that attracts international students and interns from countries like Spain, Germany, China, Iraq, Syria, and Jamaica, among others. Like its scientific counterparts, the School has been developing a modern research-and-education environment, including the implementation of mass open online courses (MOOCs), of 
which the courses of "Russian Classical Literature" and "Russian Culture Studies" being the most attractive. The School's main areas of research are of a fundamental and topical applied character, which matches the research published by $R J C$. They focus on multidimensional study of Siberian linguistic culture, research and the digitalization of the endangered and minority regional languages. For example, the School has developed a computer simulator for speech therapy of post-stroke patients with semantic aphasia, and others suffering with some type of speech defect.

The School of Philology and Language Communication is particularly proud of its longstanding and fruitful partner relations with the Russian Communication Association. In 2012 the School hosted the VI International RCA Conference "Communication in a Changing Society." The Conference's aims were to unite researchers from different countries and various domains to form a multidisciplinary paradigm of contemporary communication studies. Since that time, the School has engaged in several research collaborations with international conference participants, including Valliere Auzenne, Marilyn Young, and Michael Launer of Florida State University, USA, and Jukka Pietilainen of University of Helsinki, Finland, among others.

In addition, SibFU's School of Economics, Management and Environmental Studies offers a Business Management tract that addresses interpersonal communication and presentational skills. The School also focuses on human-computer interactions and AI (artificial intelligence) in its "Software Development" tract. These foci on human and technological communication illustrate SibFU's commitment to the traditional and newer areas of communication scholarship that are occurring globally.

SibFU's international reputation as a strong scientific university and its commitment to the study of communication through its various schools makes it the perfect Russian academic partner for $R J C$, and we look forward to its contribution to enhancing the study of communication in Russia and globally. 